\title{
Chemical Residues in Food Grains: The Burning Health Issues in Asian Countries
}

\author{
A K Mohiuddin* \\ Department of Pharmacy, World University of Bangladesh, Bangladesh
}

*Corresponding author: AK Mohiuddin, Department of Pharmacy, World University of Bangladesh, Bangladesh.

Received Date: August 27, 2019

Published Date: October 28, 2019

\begin{abstract}
Food security is a high-priority issue for sustainable global development both quantitatively and qualitatively. Once pesticides are applied, residues may be found in soil, on plant, on harvested product, on application equipment, in water and irrigation canals, in pesticide storage area, on cloth of applicant. Short term poisoning effects like nausea, vomiting, headache, chest pain, eye, skin and throat irritation etc. and potential longterm health effect like allergies, cancer, nervous system damage, birth defects, reproductive problem have been reported in recent decades, adverse effects of unexpected contaminants on crop quality have threatened both food security and human health. Heavy metals, metalloids (e.g., $\mathrm{Hg}$, As, $\mathrm{Pb}$, $\mathrm{Cd}$, and $\mathrm{Cr}$ ) from pesticides and fertilizers can jeopardize human metabolomics, contributing to morbidity and even mortality. Those during crop production include soil nutrient depletion, water depletion, soil and water contamination, and pest resistance/outbreaks and the emergence of new pests and diseases.
\end{abstract}

Keywords: pesticides; cancer; organochlorine insecticides; heavy metal poisoning; fertilizers; food-processing operations

\section{Introduction}

Growth in global population means that farmers must produce food for an estimated 9.1 billion people expected to inhabit the earth by 2050 [1] (Figure). Humans cultivate only about 150 of an estimated 50,000 edible plant species worldwide, with only 30 plant species comprising the vast majority of our diets. Just three of these (rice, maize and wheat) provide about $60 \%$ of the world's food energy intake [2,3]. These plants are susceptible to 80,000 to 100,000 diseases caused by everything from viruses to bacteria, fungi, algae, and even other higher plants [4]. Again, Food plants have to compete with some 30,000 different species of weeds worldwide, of which at least 1800 species are capable of causing serious economic losses [5]. Globally, around 20-30\% of agricultural produce is lost annually due to insect pests, diseases, weeds and rodents, viz, growth, harvest, and storage [1,6]. According to World Bank, South Asian countries are home to home to $33 \%$ of the world's poor and economies have among the highest levels of public debt in the world [7]. Mean consumption of whole grains $38.4 \mathrm{~g} /$ day in between 1990 to 2010. Southeast Asian nations along with 2/3 Sub-Saharan African regions had the highest intakes. Overall, 23 of 187 countries had mean whole grain intake $\geq 2.5$ (50 g) servings/day, representing 335 million adults and $7.6 \%$ of the world adult population [8]. Southeast Asia is a region that produces high amounts of key food commodities and includes areas of divergent socio-economic status. The major grain crops produced in the region are rice and maize [9]. The potential sources for the contamination of grains are mostly environmentally based and include air, dust, soil, water, insects, rodents, birds, animals, microbes, humans, storage and shipping containers, handling and processing equipment [10]. The rates of destruction often are higher in less developed nations and they are now accounting for a quarter of the world's pesticide use [5,11]. Therefore, judicious use of pesticides plays a major role in plant protection. Today's more than 10,400 pesticides are approved worldwide. It has been reported that the consumption of pesticides accounts two million tons every year worldwide [12]. Interestingly, many pesticides still widely used in the USA, at the level of tens to hundreds of millions of pounds annually, have been banned or are being phased out in the EU, China and Brazil [13]. Pesticide residues reported in fruits, vegetables and grains of India [14], Nepal [15], Bangladesh [16], China [17] and Indonesia [18]. Farmers habitually apply fertilizers 
and hazardous insecticides in high quantities without assessing the actual field requirements due to inadequate knowledge [1,19]. Since pesticides are directly applied on crops, fruits, and vegetables in most agricultural applications, infants, children, and adults can be exposed to pesticides by the ingestion of those pesticidecontaminated foods [20-23]. Pesticides can exist in residential air by the evaporation of volatile and semi-volatile pesticides, such as organochlorine pesticides, from crops and residential surface soil [24-27]. Soil is an important source for heavy metals (like mercury/ cadmium) in crops and vegetables since the plants' roots can absorb these pollutants from soil, and transfer them to seeds $[28,29]$. According Retamal-Salgado et.al, cadmium (Cd) distribution in the different plant organs, more than $40 \%$ of $\mathrm{Cd}$ is absorbed and translocated to the aerial part of the plant (grain and straw), and it could be directly (grains) or indirectly (animals) ingested and negatively affect humans [30]. It accumulates in the liver and kidneys for more than 30 years and causes health problems. Toxicity of this metal involves kidney and skeletal organs and is largely the result of interactions between $\mathrm{Cd}$ and essential metals, such as calcium [31-35]. China feeds $22 \%$ of the world population with $7 \%$ of the worlds arable land. Sodango et.al, reported that 20 million hectares (approximately 16.1\%) of the total arable land in China is highly polluted with heavy metals, according to Ministry of Environmental Protection (MEP), China [36]. It is estimated that between 900,000 and 1,360,000 kg arsenic per year was introduced into Bangladesh soil through contaminated groundwater used for irrigation [37]. The use of sewage sludge for agricultural purposes can be limited by the potential content of heavy metals and toxic organic compounds that pose a threat to the environment [38]. Pajewska-Szmyt et al. reported that maternal exposure to heavy metals as $\mathrm{Pb}$ or $\mathrm{Hg}$ and persistent organic pollutants were associated with children neurodevelopment delay and indirectly affects reproductive, respiratory, and endocrine system [39]. The use of pesticides has helped to increase rice yields but has also led to an increased pollution that presents a potential toxicity threat to the environment and public health [40]. Combined with outdated waste management technologies, there are potential health risks to farmers through occupational waste management practices, along with consumers through consumption of waste-contaminated products [41]. The WHO has estimated that more than three million farmers in developing countries are poisoned by agrochemicals each year [42]. In another study, WHO and UN Environmental Program estimated that one to five million cases of pesticide poisoning occur among agricultural workers each year with about 20000 fatalities [43]. Skin injury, eye injury, headache, stomachache, and fever reported in cotton workers in southern Pakistan due to pesticide exposure [44]. Pesticide induced occupational hazards has been reported to many other similar studies in Nepal [45], China [46-48], India [49-51], Bangladesh [52], Sri Lanka [53], Myanmar [54] and Philippines [55]. The US Centre for Disease Control and Prevention confirmed more than 11,000 foodborne infections in the year 2013, with several agents like viruses, bacteria, toxins, parasites, metals, and other chemicals causing food contamination [56]. Widespread agricultural use of pesticides and home storage make them easily available for acts of self-harm in many rural households. Stability of organophosphorus pesticides are also important issue [57]. It was found that malathion was more unstable than dichlorvos and diazinon, there was an over $70 \%$ loss in 90 days even at $-20^{\circ} \mathrm{C}$ in coarsely chopped form [58]. It could be another reason for haphazard use of pesticides in the field and stored food commodities [59]. Around 600 million food borne illnesses and 420,000 deaths occur each year due to poor food handling practice. Such contaminants get access to contaminate food mainly due to food handler's poor knowledge and negligence during handling activities [60,61]. Hassan et.al, says increased prevalence of diabetes in South Asia may be related to the consumption of arsenic contaminated rice depending on its content in the rice and daily amount consumed [62]. Sabir et.al, 2019 demonstarted that arsenite can bind covalently with sulfhydryl groups in insulin molecules and receptors, enzymes such as pyruvate dehydrogenase and alpha keto-glutarate dehydrogenase, and glucose transporters (GLU-T), which may result in insulin resistance [63]. According to Kumar et.al, 50\%-60\% cereal grains can be lost during the storage stage due only to the lack of technical inefficiency. Use of scientific storage methods can reduce these losses to as low as $1 \%-2 \%$ [64]. Factors like increasing climatic variability, extreme weather events, and rising temperatures pose new challenges for ensuring food and nutrition security in Asian region. The South Asian region is one of the least integrated regions according to Washington based-IFPRI [65]. Agriculturally beneficial microorganisms may also contribute directly (i.e., biological N2 fixation, P solubilization, and phytohormone production, etc.) or indirectly (i.e., antimicrobial compounds biosynthesis and elicitation of induced systemic resistance, etc.) to crop improvement and fertilizers efficiency [66]. Overuse of chemical fertilizers and pesticides have effects on the soil organisms that are similar to human overuse of antibiotics. Indiscriminate use of chemicals might work for a few years, but after a while, there aren't enough beneficial soil organisms to hold onto the nutrients [67]. Also, resistance to certain pesticides against brown planthopper (BPH), Nilaparvata lugens, and the white-backed planthoppers (WBPH), Sogatella furcifera reported in Asian countries has been reported [68-72]. Also, the higher exposure of crop plants to heavy metal stress reduces growth and yield and affect the sustainability of agricultural production [73]. Cadmium (Cd) is a well-known metal imposing threats to human health, and it can be accumulated in polished rice over the permitted range of $0.2 \mathrm{mg} \mathrm{kg-1}$ [74]. It leads to reduction in the plant productivities as well by inhibiting their growth, photosynthesis, pigments, nutrient uptake, germination, electron transport chain [75]. Applications of phosphorus-based fertilizers improve the soil fertility and agriculture yield but at the same time concerns over a number of factors that lead to environmental damage need to be addressed properly [76]. Easy availability of pesticides has another interesting but pathetic outcome. approximately 110,000 pesticide self-poisoning deaths each year from 2010 to 2014, comprising some 14\% of all global suicides [77]. According to Serrano-Medina et.al, higher rates of suicide committed in areas with intensive use of pesticides 
compared to areas with less use of pesticides [78]. In Bangladesh, self-poisoning by pesticide is responsible for about $40 \%$ of poisoning cases admitted to hospital and $8-10 \%$ of overall mortality in medical wards [79]. At the Philippine General Hospital in Metro Manila, Philippines (2000-2001), recorded pesticide poisoning cases showed that more than $80 \%$ were intentional in nature [80]. Public concern about the adverse environmental and human health impacts of organochlorine contaminants led to strict regulations on their use in developed nations since 1940 [81]. Nevertheless, DDT and several other organochlorine insecticides are still being used for agriculture and public health programs in developing countries in Asia and the South Pacific [82-86]. As a consequence, humans in this region are exposed to greater dietary levels of organochlorines.

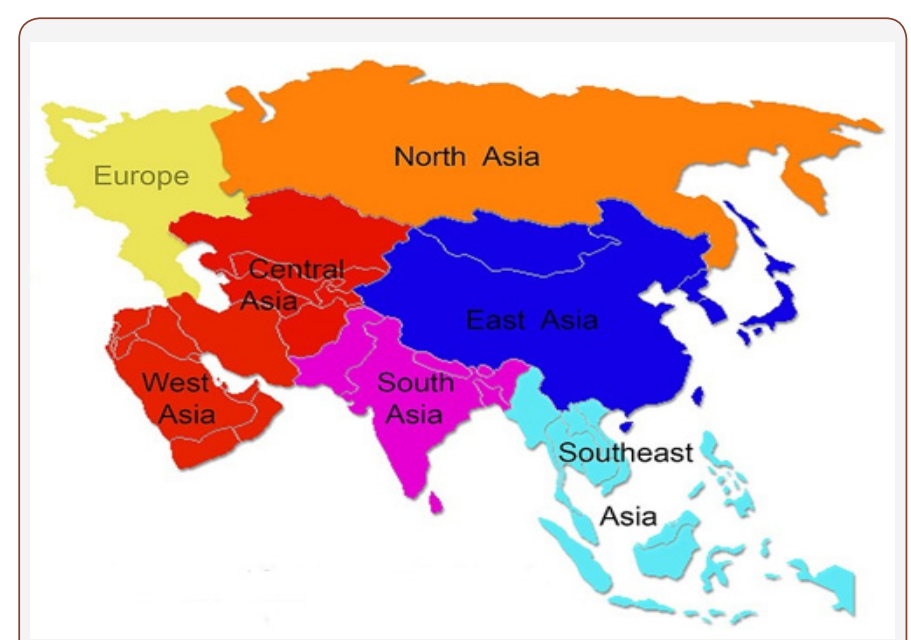

Figure 1: Classification of natural antioxidants.

\section{Recommendations}

Around 600 million food borne illnesses and 420,000 deaths occur each year due to poor food handling practice. Such contaminants get access to contaminate food mainly due to food handler's poor knowledge and negligence during handling activities $[87,88]$. Accordingly, alternative methods for exposure and risk assessment have to be developed, which vary from the use of expert opinion and pre-marketing models to the use of combination of data from the literature, measurements, and expert opinion [89]. Many studies are there to overcome fertilizer/pesticide induced health effects. Rastogi et.al, reported use of silicone nanoparticles can provide green and eco-friendly alternatives to various chemical fertilizers without harming nature [90]. It has been reported that selenium (Se) application decreases Cd uptake [75]. In similar studies, selenium, copper, zinc oxide and many other metallic nanoparticles [91-97] have been studied in food processing, packaging and preservation against phytopathogens and rodents. The washing with water or soaking in solutions of salt and some chemicals e.g. chlorine, chlorine dioxide, hydrogen peroxide, ozone, acetic acid, hydroxy peracetic acid, iprodione and detergents are reported to be highly effective in reducing the level of pesticides [98]. Various food-processing operations include sorting, trimming, cleaning, cooking, baking, frying, roasting, flaking, and extrusion that have variable effects on mycotoxins [99]. Cooking rice in excess water efficiently reduces the amount of arsenic (As) in the cooked grain [100].

\section{Acknowledgement}

I'm thankful to Dr. Zahra Hadian, Department of Food Science and Technology, National Nutrition and Food Technology Research Institute, Shahid Beheshti University of Medical Sciences, Tehran, Iran for her precious time to review my literature and for her thoughtful suggestions. I'm also grateful to seminar library of Faculty of Pharmacy, University of Dhaka and BANSDOC Library, Bangladesh for providing me books, journal and newsletters.

\section{Financial Disclosure or Funding}

None.

\section{Conflict of Interest}

The author declares that he has no competing interests.

\section{Informed Consent}

None.

\section{Author contributions}

None.

\section{References}

1. Rahaman MM, Islam KS, Jahan M (2018) Rice Farmers' Knowledge of the Risks of Pesticide Use in Bangladesh. J Health Pollut 8(20): 181203.

2. Thielecke F, Nugent AP (2018) Contaminants in Grain-A Major Risk for Whole Grain Safety? Nutrients 10(9).

3. Shelef O, Weisberg PJ, Provenza FD (2017) The Value of Native Plants and Local Production in an Era of Global Agriculture. Front Plant Sci 8: 2069.

4. Lari SZ, Khan NA, Gandhi KN, Meshram TS, Thacker NP (2014) Comparison of pesticide residues in surface water and ground water of agriculture intensive areas. J Environ Health Sci Eng 12(1): 11.

5. Robson MG, DerMarderosian AH Chapter 19. Pesticides. In: Loyd V Allen Jr (Editor) Remington: The Science and Practice of Pharmacy (2 Volumes) $22^{\text {nd }}$ Revised edition. Pharmaceutical Press, UK.

6. Food and Agriculture Organization of the UN (FAO). Controlling pests.

7. Schafer H (2019) South Asia: A bright spot in darkening economic skies? World Bank Blog (End Poverty in South Asia).

8. Micha R, Khatibzadeh S, Shi P, Andrews KG, Engell RE, et al. (2015) Global Burden of Diseases Nutrition and Chronic Diseases Expert Group (NutriCoDE). Global, regional and national consumption of major food groups in 1990 and 2010: a systematic analysis including 266 countryspecific nutrition surveys worldwide. BMJ Open 5(9): e008705.

9. Brownlee IA, Durukan E, Masset G, Hopkins S, Tee ES (2018) An Overview of Whole Grain Regulations, Recommendations and Research across Southeast Asia Nutrients 10(6).

10. Brar PK, Danyluk MD (2018) Nuts and Grains: Microbiology and Preharvest Contamination Risks. Microbiol Spectr 6(2).

11. Food and Agriculture Organization of the UN (FAO). Controlling pests.

12. Franklin N Mabe, Kwadwo Talabi, Gideon Danso-Abbeam (2017) Awareness of Health Implications of Agrochemical Use: Effects on Maize Production in Ejura-Sekyedumase Municipality, Ghana. Advances in Agriculture.

13. Donley N (2019) The USA lags behind other agricultural nations in banning harmful pesticides. Environ Health 18(1): 44. 
14. Kumari D, John S (2019) Health risk assessment of pesticide residues in fruits and vegetables from farms and markets of Western Indian Himalayan region. Chemosphere 224: 162-167.

15. Bhandari G, Zomer P, Atreya K, Mol HGJ, Yang X, et al. (2019) Pesticide residues in Nepalese vegetables and potential health risks. Environ Res 172: 511-521.

16. Mohiuddin AK (2019) Chemical Contaminants and Pollutants in the Measurable Life of Dhaka City. European Journal of Sustainable Development Research 3(1): 57-73.

17. Yu Y, Hu S, Yang Y, Zhao X, Xue J, et al. (2017) Successive monitoring surveys of selected banned and restricted pesticide residues in vegetables from the northwest region of China from 2011 to 2013. BMC Public Health. 18(1): 91.

18. Shoiful A, Fujita H, Watanabe I, Honda K (2013) Concentrations of organochlorine pesticides (OCPs) residues in foodstuffs collected from traditional markets in Indonesia. Chemosphere 90(5): 1742-50.

19. Roberts JR, Karr CJ (2012) Council On Environmental Health. Pesticide exposure in children. Pediatrics 130(6): e1765-88.

20. National Research Council (US) (1993) Committee on Pesticides in the Diets of Infants and Children. Pesticides in the Diets of Infants and Children. Washington (DC): National Academies Press, USA.

21. Nicolopoulou-Stamati P, Maipas S, Kotampasi C, Stamatis P, Hens L (2016) Chemical Pesticides and Human Health: The Urgent Need for a New Concept in Agriculture. Front Public Health 4: 148.

22. UNISEF (2018) Understanding the Impacts of Pesticides on Children: A discussion paper.

23. Centers for Ecogenetics \& Environmental Health. Fast Facts about Health Risks of Pesticides in Food.

24. Li Z, Jennings A (2017) Worldwide Regulations of Standard Values of Pesticides for Human Health Risk Control: A Review. Int J Environ Res Public Health 14(7).

25. Waliszewski SM, Carvajal O, Gómez-Arroyo S, Amador-Muñoz O, Villalobos-Pietrini R, et al. (2008) DDT and HCH isomer levels in soils, carrot root and carrot leaf samples. Bull Environ Contam Toxicol 81(4): 343-347.

26. Batterman SA, Chernyak SM, Gounden Y, Matooane M, Naidoo RN (2008) Organochlorine pesticides in ambient air in Durban, South Africa. Sci Total Environ 397(1-3): 119-30.

27. Mai C, Theobald N, Hühnerfuss H, Lammel G (2016) Persistent organochlorine pesticides and polychlorinated biphenyls in air of the North Sea region and air-sea exchange. Environ Sci Pollut Res Int 23(23): 23648-23661.

28. Zhang X, Zhong T, Liu L, Ouyang X (2015) Impact of Soil Heavy Metal Pollution on Food Safety in China. PLoS One 10(8):e0135182.

29. Li R, Wu H, Ding J, Fu W, Gan L, et al. (2017) Mercury pollution in vegetables, grains and soils from areas surrounding coal-fired power plants. Sci Rep 7: 465-45.

30. Retamal-Salgado J, Hirzel J, Walter I, Matus I (2017) Bioabsorption and Bioaccumulation of Cadmium in the Straw and Grain of Maize (Zea mays L.) in Growing Soils Contaminated with Cadmium in Different Environment. Int J Environ Res Public Health. 14(11).

31. Rodríguez J, Mandalunis PM (2018) A Review of Metal Exposure and Its Effects on Bone Health. J Toxicology.

32. Liu Y, Xiao T, Baveye PC, Zhu J, Ning Z, et al. (2015) Potential health risk in areas with high naturally occurring cadmium background in southwestern China. Ecotoxicology and Environmental Safety 112: 12231.

33. Chang YF, Wen JF, Cai JF, Xiao-Ying W, Yang L, et al. (2012) An investigation and pathological analysis of two fatal cases of cadmium poisoning. Forensic Sci Int 220(1-3): e5-8.

34. Jaishankar M, Tseten T, Anbalagan N, Mathew BB, Beeregowda KN (2014) Toxicity, mechanism and health effects of some heavy metals. Interdiscip Toxicol 7(2): 60-72.
35. Jan AT, Azam M, Siddiqui K, Ali A, Choi I, Haq QM (2015) Heavy Metals and Human Health: Mechanistic Insight into Toxicity and Counter Defense System of Antioxidants. Int J Mol Sci 16(12):29592-29630.

36. Sodango TH, Li X, Sha J, Bao Z (2018) Review of the Spatial Distribution, Source and Extent of Heavy Metal Pollution of Soil in China: Impacts and Mitigation Approaches. J Health Pollut 8(17): 53-70.

37. McCarty KM, Hanh HT, Kim KW (2011) Arsenic geochemistry and human health in South East Asia. Rev Environ Health 26(1): 71-78.

38. Kominko H, Gorazda K, Wzorek Z (2019) Potentiality of sewage sludgebased organo-mineral fertilizer production in Poland considering nutrient value, heavy metal content and phytotoxicity for rapeseed crops. J Environ Manage 248: 109283.

39. Pajewska-Szmyt M, Sinkiewicz-Darol E, Gadzała-Kopciuch R (2019) The impact of environmental pollution on the quality of mother's milk. Environ Sci Pollut Res Int 26(8): 7405-7427.

40. Stadlinger N, Berg H, Van den Brink PJ, Tam NT, Gunnarsson JS (2018) Comparison of predicted aquatic risks of pesticides used under different rice-farming strategies in the Mekong Delta, Vietnam. Environmental Science and Pollution Research 25(14): 13322-13334.

41. Lam S, Pham G, Nguyen-Viet H (2017) Emerging health risks from agricultural intensification in Southeast Asia: a systematic review. Int J Occup Environ Health 23(3): 250-260.

42. Apeh CC (2018) Farmers' Perception of the Health Effects of Agrochemicals in Southeast Nigeria. J Health Pollut 8(19): 180901.

43. Banerjee I, Tripathi SK, Roy AS, Sengupta P (2014) Pesticide use pattern among farmers in a rural district of West Bengal, India. J Nat Sci Biol Med 5(2): 313-316.

44. Memon QUA, Wagan SA, Chunyu D, Shuangxi X, Jingdong L, et al. (2019) Health problems from pesticide exposure and personal protective measures among women cotton workers in southern Pakistan. Sci Total Environ 685: 659-666.

45. Lamichhane R, Lama N, Subedi S, Singh SB, Sah RB, Yadav BK (2019) Use of Pesticides and Health Risk among Farmers in Sunsari District, Nepal. J Nepal Health Res Counc 17(1): 66-70.

46. Wang N, Wang B, Wen J, Li X, Pan L, et al. (2019) Types of Exposure Pesticide Poisoning in Jiangsu Province, China; The Epidemiologic Trend between 2006 and 2018. Int J Environ Res Public Health 16(14): E2586.

47. Jin J, Wang W, He R, Gong H (2016) Pesticide Use and Risk Perceptions among Small-Scale Farmers in Anqiu County, China. Int J Environ Res Public Health 14(1): E29.

48. Eddleston M, Phillips MR (2004) Self Poisoning with pesticides. BMJ 328(7430): 42-44.

49. Chitra GA, Muraleedharan VR, Swaminathan T, Veeraraghavan D (2006) Use of pesticides and its impact on health of farmers in South India. Int J Occup Environ Health 12(3): 228-233.

50. Satya Sai MV, Revati GD, Ramya R, Swaroop AM, Maheswari E, et al. (2019) Knowledge and Perception of Farmers Regarding Pesticide Usage in a Rural Farming Village, Southern India. Indian J Occup Environ Med 23(1): 32-36.

51. Chakraborty S, Mukherjee S, Roychoudhury S, Siddique S, Lahiri T, et al. (2009) Chronic exposures to cholinesterase-inhibiting pesticides adversely affect respiratory health of agricultural workers in India. J Occup Health 51(6): 488-497.

52. Dasgupta S, Meisner C, Mamingi N (2005) Pesticide Traders' Perception of Health Risks: Evidence from Bangladesh. World Bank Policy Research Working Paper 3777, Washington DC, USA.

53. Sivayoganathan C, Gnanachandran S, Lewis J, Fernando M (1995) Protective measure use and symptoms among agropesticide applicators in Sri Lanka. Soc Sci Med 40(4): 431-436.

54. Lwin TZ, Min AZ, Robson MG, Siriwong W (2017) Awareness of safety measures on pesticide use among farm workers in selected villages of Aunglan Township, Magway Division. Myanmar J Health Res 31: 403409. 
55. Lu JL (2017) Assessment of Pesticide-Related Pollution and Occupational Health of Vegetable Farmers in Benguet Province, Philippines. J Health Pollut 7(16): 49-57.

56. Rather IA, Koh WY, Paek WK, Lim J (2017) The Sources of Chemical Contaminants in Food and Their Health Implications. Front Pharmacol 8: 830 .

57. Guo G, Jiang N, Liu F, Bian Y (2018) Storage stability of organophosphorus pesticide residues in peanut and soya bean extracted solutions. R Soc Open Sci 5(7): 180757.

58. Bian Y, Liu F, Chen F, Sun P (2018) Storage stability of three organophosphorus pesticides on cucumber samples for analysis. Food Chemistry 250: 230-235.

59. Thapa K, Pant BR (2014) Pesticides in vegetable and food commodities: environment and public health concern. J Nepal Health Res Counc 12(28): 208-210.

60. Chekol FA, Melak MF, Belew AK, Zeleke EG (2019) Food handling practice and associated factors among food handlers in public food establishments, Northwest Ethiopia. BMC Res Notes 12(1): 20.

61. Tegegne HA, Phyo HWW (2017) Food safety knowledge, attitude and practices of meat handler in abattoir and retail meat shops of Jigjiga Town, Ethiopia. J Prev Med Hyg 58(4): E320-E327.

62. Hassan FI, Niaz K, Khan F, Maqbool F, Abdollahi M (2017) The relation between rice consumption, arsenic contamination, and prevalence of diabetes in South Asia. EXCLI J 16: 1132-1143.

63. Sabir S, Akash MSH, Fiayyaz F, Saleem U, Mehmood MH, et al. (2019) Role of cadmium and arsenic as endocrine disruptors in the metabolism of carbohydrates: Inserting the association into perspectives. Biomed Pharmacother 114: 108802.

64. Kumar D, Kalita P (2017) Reducing Postharvest Losses during Storage of Grain Crops to Strengthen Food Security in Developing Countries. Foods 6(1): 1-8.

65. Khaled MS (2018) Food systems at a crossroads in South Asia. The Financial Express.

66. Bargaz A, Lyamlouli K, Chtouki M, Zeroual Y, Dhiba D (2018) Soil Microbial Resources for Improving Fertilizers Efficiency in an Integrated Plant Nutrient Management System. Front Microbiol 9: 1606.

67. Aktar MW, Sengupta D, Chowdhury A (2009) Impact of pesticides use in agriculture: their benefits and hazards. Interdiscip Toxicol 2(1): 1-12.

68. Matsukawa M, Ito K, Kawakita K, Tanaka T (2017) Current status of insecticide susceptibility in the brown planthopper in Cambodia. J Pestic Sci 42(2): 45-51.

69. Matsukawa Nakata M, Huy Chung N, Kobori Y (2019) Insecticide application and its effect on the density of rice planthoppers, Nilaparvata lugens and Sogatella furcifera, in paddy fields in the Red River Delta, Vietnam. J Pestic Sci 44(2): 129-135.

70. Heong KL, Wong L, Hasmin J, Reyes DL (2013) Addressing Planthopper Threats to Asian Rice Farming and Food Security: Fixing Insecticide Misuse. Asian Development Bank, 6 ADB Avenue, Mandaluyong City 1550 Metro Manila, Philippines.

71. Bottrell DG, Schoenly KG (2012) Resurrecting the ghost of green revolutions past: the brown planthopper as a recurring threat to highyielding rice production in tropical Asia. J. Asia-Pacific Entom 15(1): 122-140.

72. Khoa DB, Thang BX, Liem NV, Holst N, Kristensen M (2018) Variation in susceptibility of eight insecticides in the brown planthopper Nilaparvata lugens in three regions of Vietnam 2015-2017. PLoS One 13(10): e0204962.

73. Bhat JA, Shivaraj SM, Singh P, Navadagi DB, Tripathi DK, et al. (2019) Role of Silicon in Mitigation of Heavy Metal Stresses in Crop Plants. Plants (Basel) 8(3): E71.

74. Farooq MU, Tang Z, Zheng T, Asghar MA, Zeng R, et al. (2019) Crosstalk between Cadmium and Selenium at Elevated Cadmium Stress Determines the Fate of Selenium Uptake in Rice. Biomolecules 9(6): E247.
75. Khanna K, Jamwal VL, Gandhi SG, Ohri P, Bhardwaj R (2019) Metal resistant PGPR lowered Cd uptake and expression of metal transporter genes with improved growth and photosynthetic pigments in Lycopersicon esculentum under metal toxicity. Sci Rep 9(1): 5855.

76. Gupta DK, Chatterjee S, Datta S, Veer V, Walther C (2014) Role of phosphate fertilizers in heavy metal uptake and detoxification of toxic metals. Chemosphere 108: 134-144.

77. Damalas CA, Koutroubas SD (2017) Farmers Training on Pesticide Use Is Associated with Elevated Safety Behavior. Toxics 5(3): E19.

78. Serrano Medina A, Ugalde Lizárraga A, Bojorquez Cuevas MS, Garnica Ruiz J, González Corral MA, et al. (2019) Neuropsychiatric Disorders in Farmers Associated with Organophosphorus Pesticide Exposure in a Rural Village of Northwest México. Int J Environ Res Public Health 16(5): E689.

79. Chowdhury FR, Dewan G, Verma VR, Knipe DW, Isha IT, et al. (2018) Bans of WHO Class I Pesticides in Bangladesh-suicide prevention without hampering agricultural output. Int J Epidemiol 47(1): 175-184.

80. Lu JL, Cosca KZ, Del Mundo J (2010) Trends of pesticide exposure and related cases in the Philippines. J Rural Med 5(2): 153-164.

81. Kannan K, Tanabe S, Giesy JP, Tatsukawa R (1997) Organochlorine pesticides and polychlorinated biphenyls in foodstuffs from Asian and oceanic countries. Rev Environ Contam Toxicol 152: 1-55.

82. Jayaraj R, Megha P, Sreedev P (2016) Organochlorine pesticides, their toxic effects on living organisms and their fate in the environment. Interdiscip Toxicol 9(3-4): 90-100.

83. Lammel G, Spitzy A, Audy O, Beckmann S, Codling GP, et al. (2017) Organochlorine pesticides and polychlorinated biphenyls along an eastto-west gradient in subtropical North Atlantic surface water. Environ Sci Pollut Res Int 24(12): 11045-11052.

84. Van Den Berg H, Zaim M, Yadav RS, Soares A, Ameneshewa B, et al. (2012) Global trends in the use of insecticides to control vector-borne diseases. Environ Health Perspect 120(4): 577-582.

85. Takazawa Y, Takasuga T, Doi K, Saito M, Shibata Y (2016) Recent decline of DDTs among several organochlorine pesticides in background air in East Asia. Environ Pollut 217: 134-142.

86. Ali U, Syed JH, Malik RN, Katsoyiannis A, Li J, et al. (2014) Organochlorine pesticides (OCPs) in South Asian region: a review. Sci Total Environ 476477: 705-717.

87. Chekol FA, Melak MF, Belew AK, Zeleke EG (2019) Food handling practice and associated factors among food handlers in public food establishments, Northwest Ethiopia. BMC Res Notes 12(1): 1-20.

88. Tegegne HA, Phyo HWW (2017) Food safety knowledge, attitude and practices of meat handler in abattoir and retail meat shops of Jigjiga Town, Ethiopia. J Prev Med Hyg 58(4): E320-E327.

89. Fargnoli M, Lombardi M, Puri D, Casorri L, Masciarelli E, et al. (2019) The Safe Use of Pesticides: A Risk Assessment Procedure for the Enhancement of Occupational Health and Safety (OHS) Management. Int J Environ Res Public Health. 16(3): E310.

90. Rastogi A, Tripathi DK, Yadav S, Chauhan DK, Živčák M, et al. (2019) Application of silicon nanoparticles in agriculture. 3 Biotech 9(3): 90.

91. Quiterio Gutiérrez T, Ortega Ortiz H, Cadenas Pliego G, Hernández Fuentes AD, Sandoval Rangel A, et al. (2019) The Application of Selenium and Copper Nanoparticles Modifies the Biochemical Responses of Tomato Plants under Stress by Alternaria solani. Int J Mol Sci 20(8): E1950.

92. Horky P, Skalickova S, Baholet D, Skladanka J (2018) Nanoparticles as a Solution for Eliminating the Risk of Mycotoxins. Nanomaterials (Basel) 8(9): E727.

93. C A, K Handral H, Kelmani R C (2018) A Comparative In Vivo Scrutiny of Biosynthesized Copper and Zinc Oxide Nanoparticles by Intraperitoneal and Intravenous Administration Routes in Rats. Nanoscale Res Lett 13(1): 93.

94. Alghuthaymi MA, Almoammar H, Rai M, Said Galiev E, Abd Elsalam KA (2015) Myconanoparticles: synthesis and their role in phytopathogens management. Biotechnol Biotechnol Equip 29(2): 221-236. 
95. Shah M, Fawcett D, Sharma S, Tripathy SK, Poinern GEJ (2015) Green Synthesis of Metallic Nanoparticles via Biological Entities. Materials (Basel) 8(11): 7278-7308.

96. Nandini B, Hariprasad P, Prakash HS, Shetty HS, Geetha N (2017) Trichogenic-selenium nanoparticles enhance disease suppressive ability of Trichoderma against downy mildew disease caused by Sclerospora graminicola in pearl millet. Sci Rep 7(1): 2612.

97. Pradhan N, Singh S, Ojha N, Shrivastava A, Barla A, et al. (2015) Facets of Nanotechnology as Seen in Food Processing, Packaging, and Preservation Industry. Biomed Res Int 2015: 365672.
98. Bajwa U, Sandhu KS (2014) Effect of handling and processing on pesticide residues in food-a review. J Food Sci Technol 51(2): 201-220.

99. Kaushik G (2015) Effect of processing on mycotoxin content in grains. Crit Rev Food Sci Nutr 55(12): 1672-1683.

100. Gray PJ, Conklin SD, Todorov TI, Kasko SM (2016) Cooking rice in excess water reduces both arsenic and enriched vitamins in the cooked grain. Food Addit Contam Part a Chem Anal Control Expo Risk Assess 33(1): 78-85. 